\title{
STRATEGI PENINGKATKAN PENERIMAAN RETRIBUSI PELAYANAN PASAR KOTA SERANG
}

\author{
The Strategy to Increase of Market Retribution Revenue in Serang City
}

\author{
Aradea Chandra ${ }^{1}$, Ernan Rustiadi ${ }^{2}$, Himawan Hariyoga ${ }^{3}$
}

\author{
1 Staff Direktorat Jenderal Perimbangan Keuangan, Kementerian Keuangan RI. Email: \\ aradea.chandra@gmail.com \\ 2Staff Pengajar Departemen Ilmu Tanah, Fakultas Pertanian. IPB. Email: ernan@indo.net.id \\ ${ }^{3}$ Deputi Bidang Promosi Penanaman Modal, Badan Koordinasi Penanaman Modal. Email: \\ hariyoga2@yahoo.com
}

\begin{abstract}
The era of regional autonomy requires every region to have independence in managing its regional finance in order to increase its local revenue. Market retribution is a type of retribution that can be potentially used as a source of local revenue. Serang city is one of the cities that become a merchant destination for traders from other regions due to its rapid economic development. The aim of this study is to analyze the performance of market retribution, to analyze the perception of merchants in accordance with the implementation of collection policy and to formulate the strategy to increase market retribution receipts. The primary data was obtained from interviews with the merchants and pertinent institution official that were chosen purposively (purposive sampling). Various analytical methods which were specifically implemented in order to achieve the purpose of the study are as follow: analysis of local government financial performance, descriptive statistical analysis, and analytical hierarchy process. The result of the analysis suggests that: (1) in general the performance of market retribution of Serang city in the period of 2009 to 2015 is less well; (2) according to the perception of the merchants, the endeavor of the implementation of market service retribution is running quite well; and (3) the first priority of the strategy which can be implemented in improving market retribution is the issuance of technical guidelines concerning to the attainment of market retribution collection.
\end{abstract}

Key Words: Market Retribution, Local Government Financial Performance, Strategy to Increase of Retribution Revenue, Serang City

\begin{abstract}
ABSTRAK
Era otonomi daerah mengharuskan setiap daerah memiliki kemandirian dalam mengelola keuangan daerahnya untuk meningkatkan pendapatan asli daerahnya. Retribusi pelayanan pasar merupakan salah satu jenis retribusi yang potensial sebagai sumber pendapatan asli daerah. Kota Serang menjadi salah satu tujuan pedagang dari daerah lain untuk menjual dagangannya karena perkembangan perekonomian yang pesat. Penelitian ini bertujuan untuk: mengukur kinerja retribusi pelayanan pasar, menganalisis persepsi pedagang terhadap pelaksanaan pemungutan dan merumuskan strategi meningkatkan penerimaan retribusi pelayanan pasar. Data primer diperoleh dari wawancara dengan responden pedagang dan pejabat instansi terkait dipilih secara sengaja (purposive sampling). Metode analisis yang digunakan untuk masing-masing tujuan adalah: analisis kinerja keuangan daerah, analisis statistika deskriptif, dan proses hirarki analitik (analytical hierarchy process). Hasil dari masing-masing analisis menunjukkan bahwa: (1) secara umum kinerja retribusi pelayanan pasar Kota Serang tahun 2009 hingga 2015 kurang baik; (2) berdasarkan persepsi pedagang, upaya pelaksanaan pemungutan retribusi pelayanan pasar sudah berjalan cukup baik; dan (3) strategi prioritas pertama yang dapat diimplementasikan dalam peningkatan penerimaan retribusi pelayanan pasar adalah penerbitan petunjuk teknis pelaksanaan pemungutan retribusi pelayanan pasar.
\end{abstract}

Kata Kunci: Retribusi Pelayanan Pasar, Kinerja Keuangan Pemerintah Daerah, Strategi Peningkatan Penerimaan Retribusi, Kota Serang 


\section{PENDAHULUAN}

Pasar Tradisional adalah pasar yang dibangun dan dikelola oleh Pemerintah, Pemerintah Daerah, Swasta, Badan Usaha Milik Negara dan Badan Usaha Milik Daerah termasuk kerjasama dengan swasta (Peraturan Presiden nomor 112 Tahun 2007 pasal 1 ayat 2). Peranan pasar tradisional yang sangat penting sebagai tempat usaha para pedagang kecil tidak akan mudah tergeser dari persaingan pasar modern yang banyak bermunculan saat ini (Inggawati 2013).

Sejak munculnya kebijakan otonomi daerah, setiap daerah diberikan kewenangan yang besar dalam mengelola pembangunan di daerahnya sendiri, termasuk mengelola sumber pendapatan asli daerahnya. Retribusi daerah yang menyumbang rata-rata kontribusi sebesar $18,40 \%$ terhadap pendapatan asli daerah membuat pemda Kota Serang perlu meningkatkan penerimaan dari retribusi daerah agar PAD juga semakin meningkat dan tidak tergantung hanya pada pajak daerah.

Salah satu jenis retribusi yang berpotensi dalam meningkatkan penerimaan retribusi daerah adalah retribusi pelayanan pasar. Posisi strategis Kota Serang sebagai daerah yang dilalui jalur lintas Sumatera-Jawa menyebabkan perekonomiannya cepat berkembang, terutama pada sektor perdagangan yang memberi kontribusi terbesar terhadap PDRB Kota Serang dalam lima tahun terakhir. Hal ini menjadi daya tarik bagi para pedagang di Kota Serang maupun di daerah lainnya di luar Kota Serang untuk berjualan di pasar-pasar tradisional yang berada di Kota Serang. Akan tetapi, keadaan yang terjadi tidaklah sesuai dengan apa yang diharapkan oleh pemerintah daerah dimana realisasi penerimaan dari retribusi pelayanan pasar tidak pernah mencapai target yang telah ditetapkan sejak adanya retribusi ini. 2 Berdasarkan uraian di atas, maka tujuan dari penelitian ini adalah (1) Mengukur kinerja retribusi pelayanan pasar Kota
Serang tahun 2009-015; (2) Menganalisis persepsi pedagang terhadap upaya pemungutan retribusi pelayanan pasar Kota Serang; (3) Merumuskan strategi kebijakan yang dapat diimplementasikan untuk meningkatkan penerimaan retribusi pelayanan pasar di Kota Serang.

\section{METODOLOGI}

\section{Metode Pengumpulan Data}

Penelitian ini menggunakan data primer dan data sekunder. Data primer adalah data yang dikumpulkan dari situasi aktual ketika peristiwa terjadi (Sekaran 2006). Data primer dikumpulkan melalui kuesioner dan wawancara kepada padagang dan pejabat instansi yang terkait retribusi pelayanan pasar. Data sekunder merupakan sumber yang tidak langsung memberikan data kepada pengumpul data (Sugiyono 2011). Data-data sekunder yang diperlukan yaitu data realisasi penerimaan retribusi pelayanan pasar, target penerimaan retribusi pelayanan pasar, dan realisasi retribusi daerah. Selain itu, data sekunder tersebut diperoleh dari literatur dan buku yang dapat mendukung penelitian ini. Data sekunder bersumber dari Kementerian Keuangan, Dinas Pengelola Keuangan Daerah Kota Serang, Badan Pusat Statistik Kota Serang dan Dinas Perindustrian, Perdagangan dan Koperasi Kota Serang.

\section{Metode Analisis Data}

Dalam penelitian ini, digunakan beberapa metode analisis data yaitu analisis kinerja retribusi pelayanan pasar, analisis persepsi pedagang terhadap upaya pemungutan retribusi pelayanan pasar dan analisis perumusan strategi peningkatan penerimaan retribusi pelayanan pasar.

\section{Analisis Kinerja Retribusi Pelayanan Pasar}

Dalam mengukur kinerja retribusi pelayanan pasar, analisis yang digunakan antara lain: 
1. Rasio Efektivitas Retribusi Pelayanan Pasar. Rasio ini dirumuskan sebagai berikut (Mahmudi 2010):

Efektivitas $=\frac{\text { Realiasasi Penerimaan Retribusi Pasar }}{\text { Target Penerimaan Retribusi Pasar }} \times 100 \%$

2. Laju Pertumbuhan Retribusi Pelayanan Pasar. Menurut Halim (2004) rumus pertumbuhan yang digunakan adalah :

$$
P_{i}=\frac{X_{i}-X(i-1)}{X(i-1)} \times 100 \%
$$

Keterangan:

$\mathrm{Pi}=$ Pertumbuhan retribusi pelayanan pasar tahun 2009 hingga 2015

$\mathrm{Xi}=$ Realisasi penerimaan retribusi pelayanan pasar tahun tertentu

$\mathrm{X}(\mathrm{i}-1)=$ Realisasi penerimaan retribusi pelayanan pasar tahun sebelumnya

3. Kontribusi Retribusi Pelayanan Pasar Kontribusi digunakan untuk mengetahui sejauh mana retribusi pelayanan pasar memberikan sumbangan dalam penerimaan retribusi daerah (Toduho et al 2014). Rumusnya adalah:

$$
K R P=\frac{R R P}{R R D} \times 100 \%
$$

Ket :

KRP = Kontribusi Retribusi Pasar

RRP = Realisasi Retribusi Pasar

RRD = Realisasi Retribusi Daerah

\section{Analisis Persepsi Pedagang terhadap Upaya Pemungutan Retribusi Pelayanan Pasar}

Dalam menganalisis persepsi pedagang terhadap upaya pemungutan retribusi pelayanan pasar dipilih responden sebanyak 50 pedagang pasar Rau yang terdiri dari 20 pedagang kios, 20 pedagang los dan 10 pedagang kaki lima (PKL). Metode yang digunakan adalah analisis deskriptif yaitu metode yang berkaitan dengan pengumpulan dan penyajian suatu kumpulan data hingga dapat memberikan informasi yang berguna (Walpole 1995). Skala Likert digunakan untuk mengukur sikap, pendapat, dan persepsi seseorang atau sekelompok orang tentang fenomena sosial. Dalam penelitian, fenomena sosial ini telah ditetapkan secara spesifik oleh peneliti, yang selanjutnya disebut sebagai variabel penelitian. Dengan skala Likert, maka variabel yang diukur dijabarkan menjadi indikator variabel. Kemudian indikator tersebut dijadikan sebagai titik tolak untuk menyusun item-item instrumen yang dapat berupa pernyataan atau pertanyaan (Riduwan 2010). Pengolahan data dilakukan dengan melakukan klasifikasi hasil jawaban ke dalam kelas interval yang dinyatakan dalam bentuk skor yang diolah dari perhitungan skala Likert. Menggunakan pedoman tersebut maka total rata-rata nilai skor responden disajikan dalam bentuk kontinum sebagaimana disajikan pada Gambar 1.

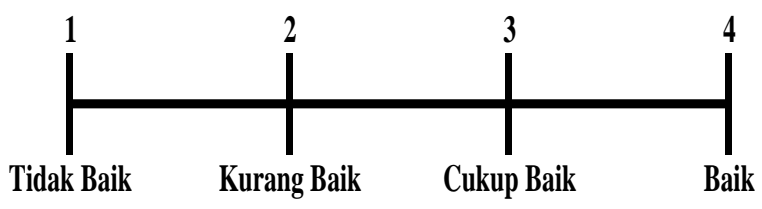

$$
\begin{gathered}
\text { Gambar } 1 \text { Kelas Interval Skor Skala } \\
\text { Likert }
\end{gathered}
$$

\section{Analisis Perumusan Strategi Peningkatan Penerimaan Retribusi Pelayanan Pasar}

\section{Analitycal Hierarchy Process} (AHP) merupakan suatu analisis yang memungkinkan kita untuk mengambil keputusan yang efektif atas persoalan kompleks dengan jalan menyederhanakan dan mempercepat proses pengambilan keputusan yang alami (Saaty 1993). Dalam merumuskan strategi kebijakan, kuesioner dan wawancara dilakukan kepada pejabat di DPKD, Disperindagkop dan UPT Pasar Kota Serang dengan pemilihan sampel secara disengaja. Hirarki yang disusun adalah 
lima level terdiri atas "Goal" yaitu peningkatan penerimaan retribusi pelayanan pasar Kota Serang; tiga "faktor" yaitu perencanaan pemungutan retribusi, fasilitas pendukung, kompetensi SDM; empat "pelaku" yaitu pemda Kota Serang, pengusaha/pedagang, petugas pemungut, masyarakat; lima "kendala" yaitu rendahnya kesadaran pedagang membayar, kurang akurat data pedagang dan tempat dagang, kurang pengawasan petugas, kurang motivasi petugas, fasilitas pendukung kurang baik; dan lima "alternatif strategi" yaitu penerbitan petunjuk teknis pelaksanaan pemungutan, peningkatan akurasi data, peningkatan sosialisasi kebijakan tarif, perbaikan sarpras pendukung dan peningkatan kualitas SDM. Berikut ini adalah beberapa proses yang harus dilakukan dalam analisis dengan AHP, yaitu sebagai berikut (Falatehan, 2016):

1. Identifikasi sistem dilakukan untuk menentukan permasalahan yang akan diselesaikan.

2. Penyusunan hierarki dilakukan dengan mengabstraksi komponen pada sistem.

3. Penyusunan matriks pendapat individu untuk setiap kriteria dan alternatif dilakukan melalui perbandingan berpasangan.

4. Penyusunan matriks pendapat gabungan, dilakukan jika responden lebih dari satu.

5. Melakukan sintesis yang digunakan untuk memperoleh perangkat prioritas menyeluruh bagi suatu persoalan keputusan.

6. Pengukuran konsistensi terhadap pengambilan keputusan. Nilai konsistensi paling tinggi adalah $10 \%$, jika lebih maka pertimbangan yang telah dilakukan perlu ditinjau ulang atau diperbaiki.

\section{HASIL DAN PEMBAHASAN}

\section{Kinerja Retribusi Pelayanan Pasar}

Suatu tingkat efektivitas, pertumbuhan dan kontribusi dapat menunjukkan peningkatan atau penurunan dari aktivitas pengelolaan keuangan daerah. Hasil yang diperoleh merupakan suatu gambaran terhadap kinerja retribusi pelayanan pasar, yang tersaji pada Tabel 1.

Tabel 1 Efektivitas Realisasi Retribusi Pelayanan Pasar Kota Serang

\begin{tabular}{cccc}
\hline Tahun & $\begin{array}{c}\text { Target }(\mathrm{Rp}) \\
\text { dalam ribuan }\end{array}$ & $\begin{array}{c}\text { Realisasi (Rp) } \\
\text { dalam ribuan }\end{array}$ & $\begin{array}{c}\text { Rasio Efektivitas } \\
(\%)\end{array}$ \\
\hline 2009 & $416.000,00$ & $206.379,50$ & 49,61 \\
2010 & $500.000,00$ & $406.355,00$ & 81,27 \\
2011 & $600.000,00$ & $469.535,00$ & 78,26 \\
2012 & $680.000,00$ & $458.035,00$ & 67,36 \\
2013 & $900.000,00$ & $435.124,00$ & 48,35 \\
2014 & $735.000,00$ & $397.037,00$ & 54,02 \\
2015 & $956.120,00$ & $814.148,36$ & 85,15 \\
\hline \multicolumn{2}{c}{ Rata-rata } \\
\hline
\end{tabular}

Sumber : Disperindagkop Kota Serang (data diolah)

Realisasi penerimaan retribusi pelayanan pasar yang semakin besar maka semakin mendekati target yang ditetapkan, dan hal tersebut menunjukkan efektivitasnya semakin baik (Dewi 2014). Efektivitas retribusi pelayanan pasar di Kota Serang dari tahun 2009 hingga 2015 mengalami fluktuatif. Rendahnya rasio efektivitas mengindikasikan beberapa hal antara lain kurang optimalnya upaya yang dilakukan oleh petugas pemungut, kemungkinan adanya kebocoran penerimaan retribusi dari petugas pemungut, atau kurangnya kesadaran 
pedagang untuk membayar. Selain dengan rasio efektivitas, kinerja realisasi retribusi pelayanan pasar juga dapat dilihat dari pertumbuhan realisasinya.
Tingkat pertumbuhan realisasi retribusi pelayanan pasar dapat dilhat pada Tabel 2 .

Tabel 2 Pertumbuhan Realisasi Retribusi Pelayanan Pasar Kota Serang

\begin{tabular}{ccc}
\hline Tahun & Realisasi $(\mathrm{Rp})$ & Pertumbuhan $(\%)$ \\
\hline 2009 & $206.379 .500,00$ & - \\
2010 & $406.355 .000,00$ & 96,90 \\
2011 & $469.535 .000,00$ & 15,55 \\
2012 & $458.035 .000,00$ & $(2,45)$ \\
2013 & $435.124 .000,00$ & $(5,00)$ \\
2014 & $397.037 .000,00$ & $(8,75)$ \\
2015 & $814.148 .365,00$ & 105,06 \\
\hline
\end{tabular}

Sumber : Disperindagkop Kota Serang (data diolah)

Berdasarkan Tabel 2 terlihat bahwa pada tahun 2010 ke tahun 2011 tingkat pertumbuhan retribusi pelayanan pasar bernilai positif dan hal ini menunjukkan kinerja retribusi pelayanan pasar pada tahun tersebut mengalami peningkatan. Namun pada 2012 hingga tahun 2014 pertumbuhan realisasi retribusi pelayanan pasar mengalami penurunan ditandai dengan pertumbuhan yang bernilai negatif dimana hal ini menunjukkan kinerja yang semakin menurun di tahuntahun tersebut dan termasuk dalam kriteria tidak berhasil. Terjadinya fluktuatif pertumbuhan ini mengindikasikan bahwa adanya suatu beban yang besar bagi pemerintah daerah Kota Serang di masa yang akan datang untuk mampu meningkatkan penerimaan retribusi pelayanan pasar.

Selanjutnya, untuk menilai kinerja retribusi pelayanan pasar dapat ditunjukkan dengan melihat besarnya kontribusi retribusi pelayanan pasar terhadap pendapatan asli daerah dan retribusi daerah dalam beberapa tahun tertentu sebagaimana terlihat pada Tabel 3.

Tabel 3 Kontribusi Realisasi Retribusi Pelayanan Pasar Kota Serang

\begin{tabular}{|c|c|c|c|c|c|}
\hline \multirow[b]{2}{*}{ Tahun } & \multirow[b]{2}{*}{$\begin{array}{c}\text { Realisasi } \\
\text { PAD } \\
\text { (Rp) dalam juta }\end{array}$} & \multirow[b]{2}{*}{$\begin{array}{c}\text { Retribusi } \\
\text { Daerah } \\
\text { (Rp) dalam juta }\end{array}$} & \multirow{2}{*}{$\begin{array}{c}\text { Retribusi } \\
\text { Pelayanan } \\
\text { Pasar } \\
\text { (Rp) dalam ribu }\end{array}$} & \multicolumn{2}{|c|}{ Kontribusi (\%) } \\
\hline & & & & $\begin{array}{c}\text { Terhadap } \\
\text { PAD }\end{array}$ & $\begin{array}{c}\text { Terhadap } \\
\text { Retribusi } \\
\text { Daerah }\end{array}$ \\
\hline 2009 & $17.923,43$ & $4.751,22$ & $206.379,50$ & 1,15 & 4,34 \\
\hline 2010 & $25.098,79$ & $10.006,78$ & $406.355,00$ & 1,62 & 4,06 \\
\hline 2011 & $41.890,33$ & $7.009,70$ & $469.535,00$ & 1,12 & 6,70 \\
\hline 2012 & $58.667,91$ & $7.666,80$ & $458.035,00$ & 0,78 & 5,97 \\
\hline 2013 & $65.376,08$ & $10.539,09$ & $435.124,00$ & 0,67 & 4,13 \\
\hline 2014 & $97.827,59$ & $8.594,26$ & $397.037,00$ & 0,41 & 4,62 \\
\hline 2015 & $111.062,81$ & $8.792,21$ & $814.148,40$ & 0,73 & 9,26 \\
\hline \multicolumn{4}{|c|}{ Rata-rata } & 0,93 & 5,58 \\
\hline
\end{tabular}

Sumber : DPKD Kota Serang (data diolah)

Berdasarkan Tabel 3 dapat dilihat bahwa kontribusi retribusi pelayanan pasar terhadap PAD maupun terhadap retribusi daerah masih sangat kurang. Hal ini terjadi bisa karena kurang efektifnya upaya pemungutan retribusi pelayanan pasar maupun belum tergalinya secara optimal potensi retribusi pelayanan pasar. 


\section{Analisis Persepsi Pedagang terhadap Upaya Pemungutan Retribusi Pelayanan Pasar di Kota Serang}

Pada bagian ini akan dijelaskan evaluasi terhadap upaya pemungutan retribusi pelayanan pasar yang dilakukan oleh aparat pemungut/Pemda Kota Serang untuk menjawab tujuan penelitian yang kedua tentang persepsi pedagang terkait kondisi yang sesungguhnya dan hasil yang diharapkan untuk dicapai dalam upaya pemungutan retribusi pelayanan pasar tersebut. Semakin besar skor yang dicapai maka semakin baik implementasi kegiatan yang telah dilakukan. Unsur-unsur yang dianalisis terdiri dari kualitas sumber daya manusia pemungut retribusi pelayanan pasar, pelaksanaan dan pengawasan pemungutan retribusi pelayanan pasar dan kondisi fasilitas lainnya yang terkait dengan proses pemungutan retribusi pelayanan pasar di Kota Serang.

\section{Kompetensi SDM Pemungut Retribusi Pelayanan Pasar}

Aspek yang dinilai dalam kompetensi SDM terdiri dari 9 item pertanyaan yaitu pemungutan sesuai tarif, kesesuaian karcis retribusi, waktu memungut, tanggapan atas keluhan pedagang, keramahan, ketegasan, kedisiplinan, kejujuran dan cara berpakaian petugas pungut. Berdasarkan pengukuran yang dilakukan terhadap persepsi responden, diperoleh skor total dari pengisian kuesioner pada keseluruhan unsur kompetensi SDM pemungut adalah $1.215(67,50 \%$ dari total nilai maksimum yang bisa dicapai) atau 2,73 (Likert skala 4).

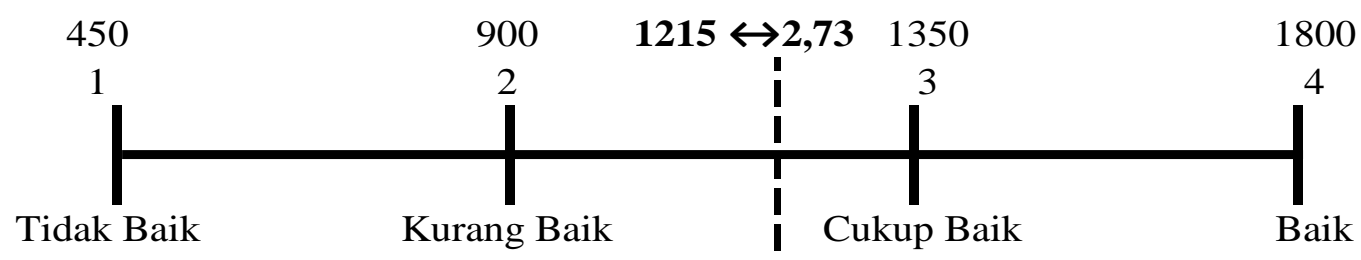

Gambar 2 Garis Kontinum Kompetensi SDM Pemungut Retribusi

Perolehan skor analisis digambarkan dalam bentuk garis kontinum menunjukkan bahwa kondisi kompetensi sumber daya manusia pemungut masih belum berada pada kondisi yang baik karena posisi skor terletak dalam interval kurang baik dan cukup baik namun sudah mendekati cukup baik. Artinya adalah pemda masih harus terus meningkatkan kompetensi SDM pemungut retribusi pelayanan pasar dengan cara meningkatkan keterampilan maupun perbaikan sikap para petugas pemungut agar menjadi lebih baik. Hal ini sesuai dengan penelitian Azmy (2015) yang menyatakan bahwa pengembangan kompetensi sumber daya manusia perlu dilakukan untuk mencapai suatu tujuan organisasi.

\section{Pelaksanaan dan Pengawasan Retribusi Pelayanan Pasar}

Pelaksanaan dan pengawasan retribusi pelayanan pasar merupakan unsur kedua yang dinilai oleh responden terkait kondisi yang terjadi selama proses pemungutan retribusi pelayanan pasar yang dilakukan oleh pemda Kota Serang. Penilaian terhadap pelaksanaan dan pengawasan retribusi pelayanan pasar terdiri dari 8 item pertanyaan yaitu besaran tarif, jumlah petugas pungut, proses pembayaran, penyuluhan tarif, pengecekan rutin karcis, pemberian sanksi, informasi perubahan tarif dan pendataan pedagang secara berkala. Berdasarkan pengukuran yang dilakukan diperoleh hasil bahwa skor total hasil pengisian kuesioner pada keseluruhan unsur pelaksanaan dan pengawasan retribusi pelayanan pasar adalah 970 


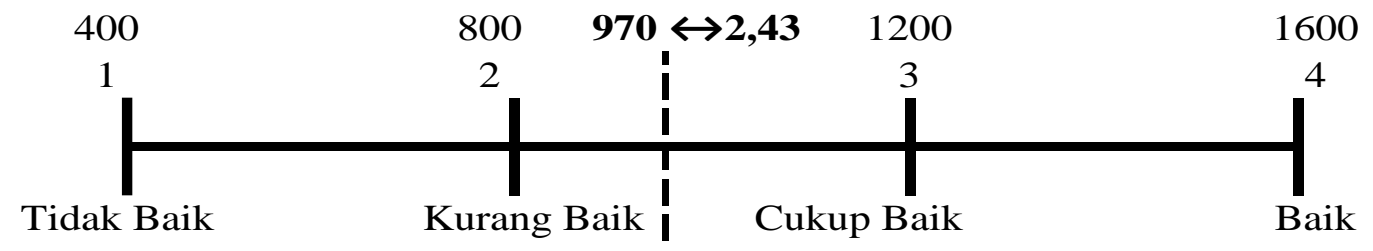

Gambar 3 Garis Kontinum Pelaksanaan dan Pengawasan Retribusi

Perolehan skor hasil yang diperoleh digambarkan dalam bentuk garis kontinum menunjukkan bahwa pelaksanaan dan pengawasan retribusi pelayanan pasar di Kota Serang masih belum berjalan baik, berada di interval kurang baik dan cukup baik, bahkan cenderung mendekati posisi yang kurang baik. Hal ini berarti bahwa pelaksanaan dan pengawasan yang telah dilakukan pemda Kota Serang selama ini masih perlu banyak perbaikan dan upaya yang lebih baik lagi agar komponen-komponen pelaksanaan maupun pengawasan dalam upaya pemungutan retribusi pelayanan pasar di Kota Serang.

\section{Kondisi Fasilitas Pendukung Lainnya}

Variabel ketiga yang dinilai oleh responden terkait upaya peningkatan penerimaan retribusi pelayanan pasar yaitu kondisi fasilitas pendukung lainnya. Penilaian kondisi fasilitas pendukung lainnya terdiri atas 14 item pertanyaan yaitu luas bangunan, tata letak bangunan, sirkulasi udara dan kondisi jalan, kualitas bangunan, pemeliharaan rutin, kualitas kamar mandi, penataan tempat parkir, kondisi penerangan, ketertiban, kenyamanan, pengendalian preman, kemudahan pengurusan sewa, keadilan dan kepastian hukum, dan akses jalan. Berdasarkan pengukuran yang dilakukan terhadap kondisi fasilitas pendukung lainnya, skor total yang diperoleh sebesar $1.640(58,57 \%$ dari total nilai maksimum yang bisa dicapai) atau 2,40 (Likert skala 4).

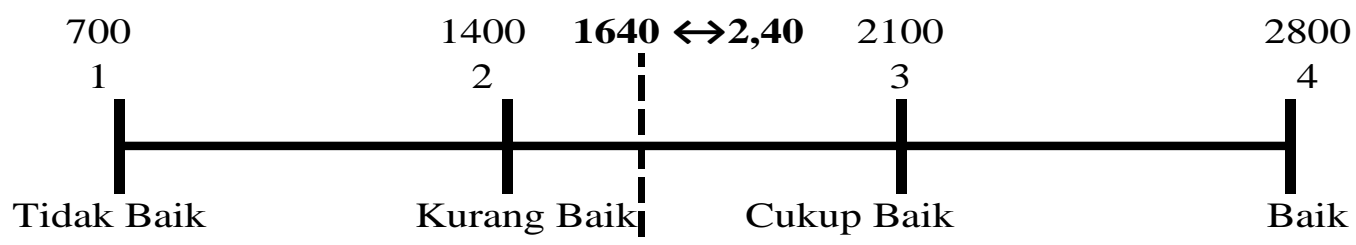

Gambar 4 Garis Kontinum Kondisi Fasilitas Pendukung Lainnya

Dari nilai skor yang diperoleh dapat digambarkan dalam bentuk garis kontinum menunjukkan bahwa kondisi fasilitas pendukung lainnya dinilai sudah cukup baik. Akan tetapi, skor nilai tersebut berada pada interval kurang baik dan cukup baik, dan sedikit menuju posisi kurang baik. Artinya kondisi fasilitas pendukung lainnya ini jika tidak diperhatikan dan dijaga dengan baik, maka ada peluang masuk pada kriteria kurang baik.

Berdasarkan analisis persepsi pedagang terhadap upaya pemungutan retribusi pelayanan pasar yang dilakukan aparat pemda selama ini yang sudah diuraikan diatas, maka secara keseluruhan hasil dari masing-masing variabel tersebut dapat disajikan pada Tabel 4. 


\section{Tabel 4 Persepsi Responden Terhadap Upaya Pemungutan Retribusi Pelayanan} Pasar Kota Serang Tahun 2017

\begin{tabular}{|c|c|c|c|c|}
\hline No & Variabel & $\begin{array}{c}\text { Nilai } \\
\text { Persepsi }\end{array}$ & Skor Ideal & Kriteria \\
\hline 1 & Kompetensi SDM Pemungut & 2,73 & 4,00 & $\begin{array}{c}\text { Mendekati } \\
\text { Cukup Baik }\end{array}$ \\
\hline 2 & $\begin{array}{l}\text { Pelaksanaan dan Pengawasan } \\
\text { Retribusi Pelayanan Pasar }\end{array}$ & 2,43 & 4,00 & $\begin{array}{l}\text { berkirsar Cukup- } \\
\text { Kurang }\end{array}$ \\
\hline 3 & $\begin{array}{l}\text { Kondisi Fasilitas Pendukung } \\
\text { Lainnya }\end{array}$ & 2,40 & 4,00 & $\begin{array}{l}\text { berkirsar Cukup- } \\
\text { Kurang }\end{array}$ \\
\hline & Rata-rata & 2,52 & & $\begin{array}{l}\text { berkirsar Cukup- } \\
\text { Kurang }\end{array}$ \\
\hline
\end{tabular}

Dari Tabel 4 secara keseluruhan nilai skor dari masing-masing variabel upaya pemungutan retribusi pelayanan pasar tersebut dapat disimpulkan bahwa upaya yang telah dilakukan oleh pemda atau pengelola pasar dalam pemungutan retribusi pelayanan pasar berada pada area interval kurang baik menuju cukup baik. Hal ini dibuktikan bahwa dari 31 pertanyaan yang disampaikan, skor kriterium yang diperoleh secara keseluruhan adalah 3.825 (61,69\% dari total nilai maksimum yang bisa dicapai) atau 2,52 (Likert skala 4). Jika digambarkan menurut garis kontinum yang mengacu pada skor tersebut diperoleh hasil sebagaimana Gambar 5.

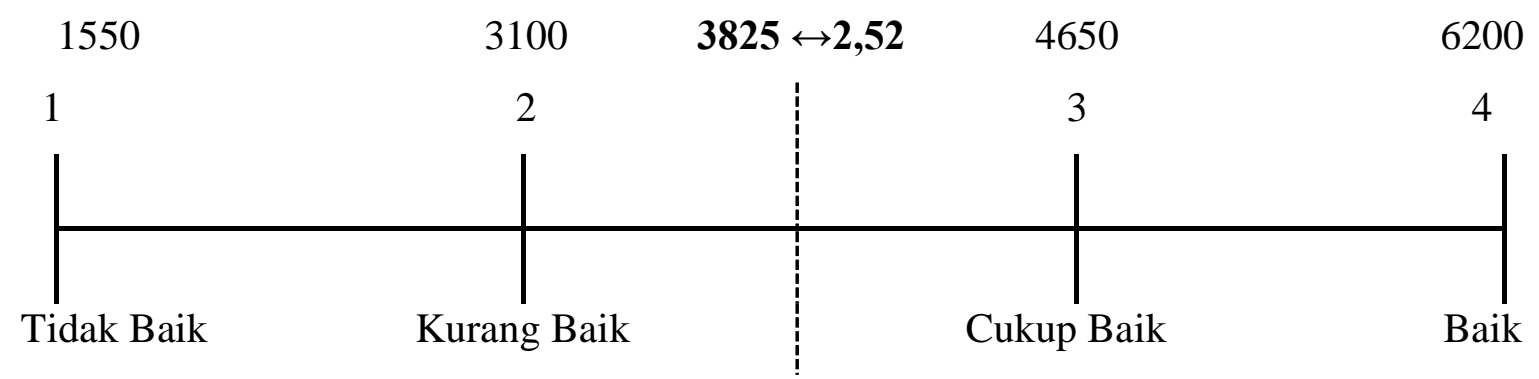

\section{Gambar 5 Garis Kontinum Upaya Pemungutan Retribusi Pelayanan Pasar Kota Serang}

Terdapat beberapa hal yang dianggap perlu untuk segera dibenahi karena skor nilai berada di bawah 2,00 yaitu penyuluhan terkait tarif dan cara pembayaran retribusi $(1,92)$, jumlah petugas pungut retribusi $(1,98)$ dan pengendalian preman/penggangu lainnya $(1,98)$.

\section{Strategi Peningkatan Penerimaan Retribusi Pelayanan Pasar}

Berdasarkan hasil analisis data dari kuesioner AHP diperoleh urutan prioritas strategi yaitu penerbitan petunjuk teknis pelaksanaan pemungutan retribusi pelayanan pasar sebagai urutan pertama dengan nilai 0,282. Diikuti secara berturut-turut peningkatan kualitas dan kuantitas SDM pemungut $(0,211)$, peningkatan akurasi data pedagang dan tempat dagang $(0,196)$, perbaikan sarana dan prasarana pendukung kegiatan pasar $(0,164)$ dan peningkatan sosialisasi kebijakan tarif retribusi pelayanan pasar $(0,146)$. Prioritas masing-masing level tersaji dalam Gambar 6.

Perbandingan antar elemen "faktor" berdasarkan "goal" meningkatkan penerimaan retribusi pelayanan pasar Kota Serang, yaitu urutan pertama perencanaan pemungutan retribusi pelayanan pasar dengan nilai 0,614, urutan selanjutnya berturut-turut adalah kompetensi sumber daya manusia (SDM) 
pemungut dengan nilai 0,230 dan fasilitas pendukung kegiatan dagang di pasar dengan nilai 0,156 . Perencanaan pemungutan retribusi pelayanan pasar dinilai sebagai prioritas utama dibandingkan dengan faktor lainnya dikarenakan perencanaan dalam upaya pemungutan retribusi pelayanan pasar adalah sangat penting terutama dalam hal penentuan potensi dan target penerimaan, pelaksanaan dan pengawasan pemungutan maupun kegiatan-kegiatan atau program-program lainnya yang berkaitan dengan upaya pemungutan retribusi pelayanan pasar seperti kegiatan sosialisasi besaran tarif retribusi.
Menurut hasil analisis AHP, perbandingan antar unsur "pelaku" berdasarkan "faktor" yaitu prioritas pertama adalah pemerintah daerah Kota Serang dengan nilai 0,498, diikuti berturut-turut yaitu petugas pemungut retribusi dengan nilai 0,214 , pengusaha/pedagang dengan nilai 0,158 dan terakhir adalah masyarakat/pembeli dengan nilai 0,130. Pemerintah daerah Kota Serang dinilai memiliki peranan dan wewenang paling besar dalam upaya meningkatkan penerimaan retribusi pelayanan pasar karena merupakan lembaga atau institusi yang langsung berkaitan dengan kebijakan dan kegiatan pemungutan retribusi pelayanan pasar.

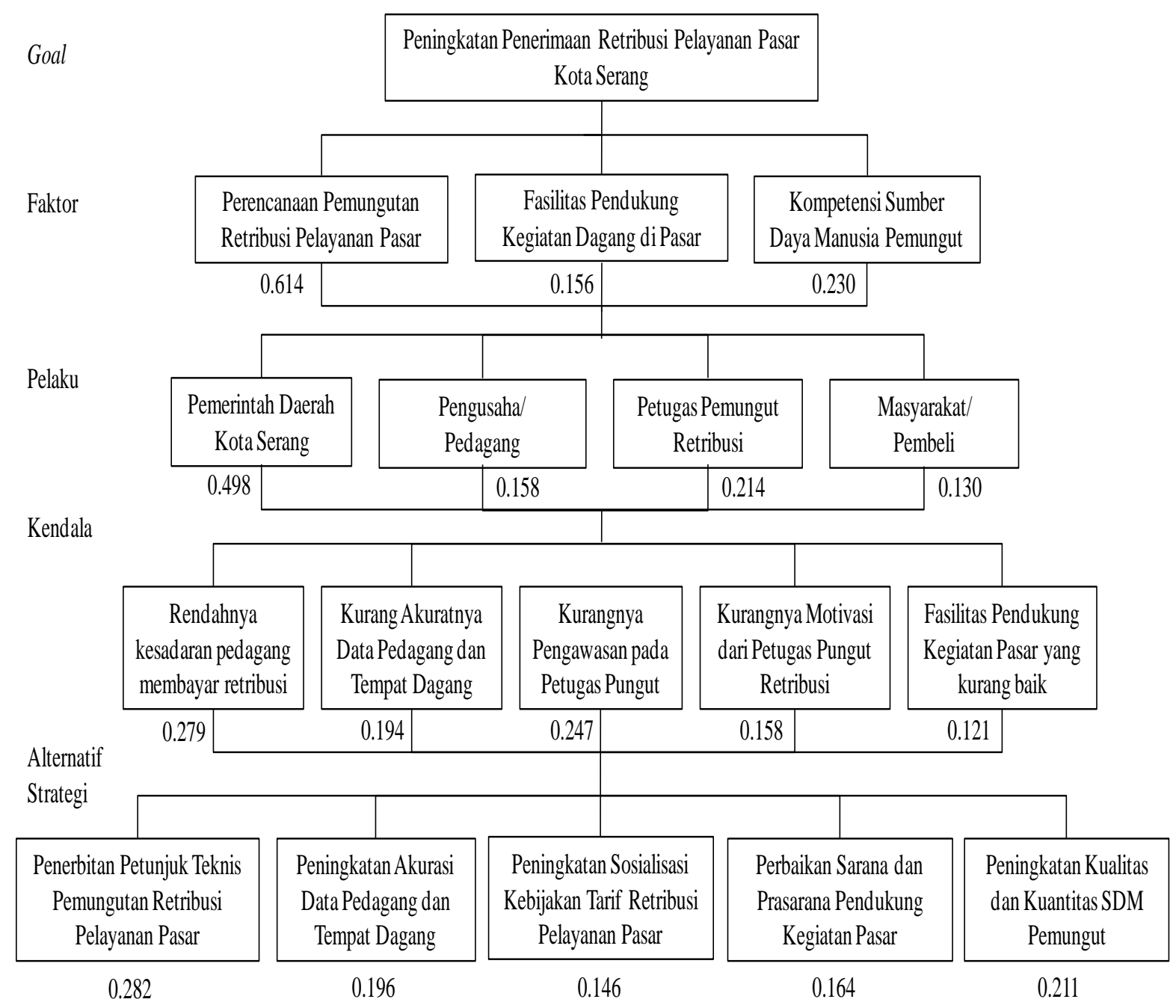
Gambar 6 Struktur dan Nilai Bobot Hirarki AHP Strategi Peningkatan
PenerimaanRetribusi Pelayanan Pasar Kota Serang 
Pemerintah daerah Kota Serang memiliki fungsi dalam pembuatan peraturan tentang perhitungan potensi dan target penerimaan retribusi, pedoman pelaksanaan pemungutan, pengawasan maupun evaluasi terhadap kinerja retribusi pelayanan pasar.

Perbandingan antar elemen "kendala" berdasarkan "pelaku" yaitu urutan pertama adalah rendahnya kesadaran pedagang dalam membayar retribusi dengan nilai 0,279. Kendala selanjutnya yaitu kurangnya pengawasan pada petugas pemungut dengan nilai 0,247 . Urutan ketiga, keempat dan kelima secara berturut-turut adalah berupa kendala kurang akuratnya data pedagang dan tempat dagang dengan nilai 0,194, kurangnya motivasi petugas pemungut retribusi dengan nilai 0,158 dan fasilitas pendukung kegiatan pasar yang kurang baik dengan nilai 0,121 .

Berdasarkan hasil wawancara dengan responden, penerbitan petunjuk teknis pemungutan retribusi pelayanan pasar merupakan strategi pertama yang harus diterapkan untuk dapat menerapkan strategi-strategi selanjutnya. Selama ini, pemungutan retribusi pelayanan pasar didasarkan atas Peraturan Daerah Kota Serang Nomor 13 Tahun 2011 tentang Retribusi Daerah dan tidak ada peraturan turunan setelahnya. Dalam peraturan tersebut hanya mengatur retribusi pelayanan pasar secara umum seperti besaran sewa tempat dagang, besaran tarif retribusi per jenis tempat dagang, subjek retribusi, objek retribusi dan sasaran retribusi pelayanan pasar. Sedangkan tata cara pengelolaan seperti masa retribusi dan cara mengukur tingkat penggunaan jasa, tata cara pemungutan, tata cara pembayaran dan sanksi administrasi belum diatur dengan dasar hukum yang jelas.

\section{Implikasi Kebijakan}

\section{Penerbitan Petunjuk \\ Teknis Pemungutan Pasar}

Berdasarkan hasil wawancara dengan responden, penerbitan petunjuk teknis pemungutan retribusi pelayanan pasar merupakan strategi pertama yang harus diterapkan untuk dapat menerapkan strategi-strategi selanjutnya. Selama ini, pemungutan retribusi pelayanan pasar didasarkan atas Peraturan Daerah Kota Serang Nomor 13 Tahun 2011 tentang Retribusi Daerah dan tidak ada peraturan turunan setelahnya. Dalam peraturan tersebut hanya mengatur retribusi pelayanan pasar secara umum seperti besaran sewa tempat dagang, besaran tarif retribusi per jenis tempat dagang, subjek retribusi, objek retribusi dan sasaran retribusi pelayanan pasar.

Petunjuk pelaksanaan retribusi pelayanan pasar mencakup hal-hal yang lebih spesifik dan detil terkait pemungutan retribusi pelayanan pasar. Misalnya, dalam Peraturan Walikota Surakarta nomor 14 tahun 2016 tentang Petunjuk Pelaksanaan Retribusi Pelayanan Pasar tertuang beberapa hal yang menjadi acuan dalam kegiatan pemungutan retribusi pelayanan pasar, antara lain terdapat bab tentang nama, objek, subjek dan golongan retribusi, bab tata cara pengelolaan seperti masa retribusi dan cara mengukur tingkat penggunaan jasa, bab tata cara pemungutan, tata cara pembayaran dan sanksi administrasi.

\section{Peningkatan Kualitas dan Kuantitas Pemungut}

Kuantitas sumber daya manusia (SDM) menjadi faktor yang bisa mempengaruhi upaya peningkatan pendapatan asli daerah, tidak terkecuali kuantitas petugas pemungut retribusi pelayanan pasar. Berdasarkan data dari Unit Pelaksana Teknis Pasar Kota Serang, terdapat kurang lebih 60 orang petugas pemungut retribusi pelayanan 
pasar yang tersebar di keenam pasar yang ada di Kota Serang. Hal ini cukup kecil dibandingkan dengan jumlah pedagang yang ada di pasar Kota Serang, yaitu kurang lebih 3.500 pedagang (kios, los dan pedagang kaki lima). Dengan terus berkembangnya perekonomian dan bertambahnya pedagang yang berdagang di pasar-pasar tradisional di Kota Serang, maka petugas pemungut retribusi pelayanan pasar juga perlu ditambah jumlahnya agar mempercepat pencapaian target penerimaan retribusi pelayanan pasar tersebut.

Selain dari segi jumlah, kualitas dari petugas pemungut retribusi perlu juga ditingkatkan. Kegiatan-kegiatan pelatihan softskill maupun pembekalan ilmu tentang retribusi pelayanan pasar perlu diberikan kepada petugas pemungut agar dalam proses pemungutan retribusi kepada pedagang, para petugas pemungut dapat melakukan pendekatan dan sikap yang baik saat melakukan pungutan maupun dapat menjelaskan dengan baik tentang pentingnya retribusi pelayanan pasar jika ada pedagang yang tidak mau membayar dengan berbagai alasan.

\section{Peningkatan Akurasi Data Pedagang dan Tempat Dagang}

Dalam merencanakan suatu anggaran atau penentuan target penerimaan suatu jenis sumber pendapatan asli daerah, perlu didukung dengan data yang akurat. Akurasi data tesebut sangat penting dalam menghitung target yang akan ditetapkan dan melihat potensi serta sumber daya yang ada. Retribusi pelayanan pasar sebagai salah satu sumber pendapatan dari retribusi daerah tidak terkecuali harus melakukan pemutakhiran data yang berhubungan dengan retribusi pelayanan pasar. Data yang perlu dan harus selalu dilakukan pemutakhiran antara lain data jumlah pedagang dan jumlah tempat dagang seperti kios, los maupun pedagang kaki lima. Akurasi data penting dilakukan agar menjadi dasar bagi pemerintah daerah khususnya Disperindagkop dalam menghitung target berdasarkan potensi retribusi yang ada.

Sejak berdirinya Kota Serang tahun 2008, retribusi pelayanan pasar sudah ada dan menjadi salah satu sumber retribusi daerah Kota Serang. Akan tetapi, hasil kinerja realisasi penerimaannya selama ini kurang efektif dalam pencapaian target yang ditetapkan. Hal ini disebabkan salah satunya oleh penetapan target yang ditetapkan tidak melihat kepada potensi yang sebenarnya. Untuk itu, penting bagi pemda untuk melakukan pemutakhiran dan akurasi data secara berkala guna menjadi dasar penetapan target penerimaan retribusi pelayanan pasar yang realistis.

\section{Perbaikan Sarana dan Prasarana Pendukung Kegiatan Pasar}

Salah satu faktor penting dalam penyelenggaraan kegiatan retribusi pelayanan pasar adalah kondisi fasilitas pendukung kegiatan pasar yang baik dan layak bagi para pedagang maupun pembeli. Selama ini, kesan pasar tradisional yang kotor, bau, tidak rapi dan tidak tertib sudah melekat diingatan setiap orang. Untuk itu, perhatian pemda maupun pedagang dan pembeli terhadap kualitas sarana dan prasarana pendukung kegiatan pasar ini harus lebih baik. Pemda selaku pemilik tempat dagang harus melakukan pemeliharaan berkala, seperti perbaikan sistem penerangan di dalam pasar, kebersihan lorong dan toilet pasar, penataan gubuk-gubuk dagang kaki lima, area parkir yang aman dan rapi serta kenyamanan dan keamanan dari preman dan penggangu lainnya.

Penciptaan kondisi pasar yang nyaman dan bersih dapat diwujudkan apabila setiap elemen masyarakat dan aparat pemda bisa berkontribusi dengan baik dalam memelihara fasilitas yang disediakan. Kerjasama dan koordinasi antar dinas seperti dinas kesehatan, dinas pekerjaan umum maupun dinas perindustrian dan perdagangan dalam perbaikan dan pemeliharaan sarana dan prasarana pendukung kegiatan pasar perlu 
disinergikan dengan baik, tidak berjalan sendiri-sendiri. Dengan adanya sinergi, maka akan lebih meringankan dalam hal penganggarannya seperti anggaran biaya pemeliharaan maupun anggaran biaya perbaikan.

\section{Peningkatan Sosialisasi Kebijakan Tarif Retribusi Pelayanan Pasar}

Dalam hal tarif retribusi pelayanan pasar, masih banyak pedagang yang belum mengetahui seberapa besar tarif sebenarnya yang harus mereka bayar. Hal ini dikarenakan kurangnya informasi yang disampaikan oleh petugas pemungut terhadap besaran tarif yang berbeda-beda bagi setiap jenis tempat dagang. Ada pedagang yang beranggapan bahwa tarif retribusi sama untuk setiap jenis tempat dagang. Ada juga pedagang yang membayar tarif retribusi hanya pada satu tempat dagang saja padahal memiliki lebih dari satu tempat dagang.

Hal-hal tersebut di atas menunjukkan bahwa petugas pemungut atau secara umum pemda Kota Serang belum melakukan sosialisasi tarif retribusi dengan baik sehingga tercipta berbagai pendapat yang salah dari para pedagang tentang besaran maupun cara pembayaran retribusi pelayanan pasar selama ini.

\section{SIMPULAN}

Berdasarkan hasil dan pembahasan yang telah disajikan sebelumnya, maka dapat disimpulkan beberapa hal sebagai berikut:

1. Berdasarkan analisis kinerja keuangan daerah, secara umum dapat digambarkan bahwa kinerja retribusi pelayanan pasar Kota Serang tahun 2009 hingga 2015 menunjukkan kinerja yang kurang baik. Untuk itu pemerintah daerah Kota Serang perlu memperbaiki perencanaan dan pengelolaan pemungutan retribusi pelayanan pasar agar dapat mengurangi kemungkinan permasalahan yang ada, seperti mengurangi kebocoran penerimaan, perhitungan target berdasarkan potensi yang sebenarnya, dan ketegasan petugas pemungut dalam melakukan proses pemungutan.

2. Menurut persepsi pedagang, upaya pelaksanaan pemungutan retribusi pelayanan pasar yang telah dilakukan oleh pemerintah daerah Kota Serang berkisar antara kurang baik dan cukup baik. Beberapa aspek yang perlu segera dilakukan perbaikan yaitu pada pelaksanaan dan pengawasan pemungutan retribusi dan kondisi fasilitas pendukung lainnya.

3. Strategi peningkatan penerimaan retribusi pelayanan pasar Kota Serang sesuai urutan prioritasnya yaitu (a) penerbitan petunjuk teknis pelaksanaan pemungutan retribusi pelayanan pasar, (b) peningkatan kualitas dan kuantitas SDM pemungut, (c) peningkatan akurasi data pedagang dan tempat dagang, (d) perbaikan sarana dan prasarana pendukung kegiatan pasar, dan (e) peningkatan sosialisasi kebijakan tarif retribusi pelayanan pasar.

4. Petunjuk teknis pelaksanaan retribusi pelayanan pasar agar dapat segera diterbitkan mengingat pedoman dalam kegiatan pemungutan retribusi pelayanan pasar masih berdasarkan Peraturan Daerah Kota Serang Nomor 13 Tahun 2011 tentang Retribusi Daerah yang berisi aturan tentang retribusi secara umum. Dengan terbitnya petunjuk teknis pelaksanaan retribusi pelayanan pasar diharapkan menjadi landasan pemda Kota Serang dalam menyusun kebijakan yang terkait dengan retribusi pelayanan pasar seperti perhitungan target berdasarkan potensi yang sebenarnya, tata cara pengelolaan retribusi maupun sanksi terhadap wajib retribusi yang tidak membayar retribusi sesuai dengan aturan yang berlaku. 


\section{DAFTAR PUSTAKA}

Azmy A. 2015. Pengembangan Kompetensi Sumber Daya Manusia untuk Mencapai Career Ready Professional di Universitas Tanri Abeng. Binus Bussiness Review Volume 6 No.2, Agustus 2015:220232. Tanri Abeng University. Jakarta. (ID)

Dewi OC. 2014. Analisis Kinerja Penerimaan Retribusi Pasar di Kabupaten Sleman Tahun 20062010. Diponegoro Journal of Economcis Volume 3 No.2, Januari 2014:1-12. Universitas Diponegoro. Semarang. (ID)

Falatehan AF. 2016. Analytical Hierarchy Process (AHP) :Teknik Pengambilan Keputusan untuk Pembangunan Daerah. Indomedia Pustaka. Yogyakarta. (ID)

Halim A. 2004. Manajemen Keuangan Daerah. UPP AMP YKPN. Yogyakarta. (ID)

Inggawati MRD, Ngadiman, Muhtar. 2013. Strategi Optimalisasi Retribusi Daerah dalam Rangka Meningkatkan Pendapatan Asli Daerah (PAD) : Studi pada Dinas Pasar Kabupaten Sleman. Jurnal Pendidikan Ekonomi UNS Volume 2 No.1, Juli 2013:1-10. Universitas Sebelas Maret. Surakarta. (ID)

Mahmudi. 2010. Analisis Laporan Keuangan Pemerintah Daerah. STIM YKPM. Yogyakarta. (ID)

Pemerintah Kota Serang. 2011. Peraturan Daerah Kota Serang Nomor 13 Tahun 2011 tentang Retribusi Daerah. Sekretariat Daerah. Serang. (ID)

Pemerintah Republik Indonesia. 2007. Peraturan Presiden Nomor 112 Tahun 2007 tentang Penataan Dan Pembinaan Pasar Tradisional, Pusat Perbelanjaan Dan Toko Modern. Sekretariat Negara. Jakarta. (ID)
Riduwan. 2010. Skala Pengukuran Variabel-variabel Penelitian. Alfabeta. Bandung. (ID)

Saaty TL. 1993. Pengambilan Keputusan Bagi Para Pemimpin. PT. Pustaka Binaman Pressindo. Jakarta. (ID)

Sekaran U. 2006. Metodologi Penelitian untuk Bisnis. Edisi 4. Salemba Empat. Jakarta. (ID)

Sugiyono. 2011. Metode Penelitian Kombinasi. Alfabeta Bandung. Bandung. (ID)

Toduho DAM, Saerang DPE, Elim I. 2014. Penerimaan Retribusi Pasar dalam Upaya Meningkatkan Pendapatan Asli Daerah Kota Tidore Kepulauan. Jurnal EMBA Volume 2 No.2, Juni 2014:10901103. Universitas Sam Ratulangi. Manado. (ID)

Walpole RE. 1995. Pengantar Statistika, edisi ke-3. PT. Gramedia Pustaka Utama. Jakarta. (ID) 